University of Warwick institutional repository: http://go.warwick.ac.uk/wrap This paper is made available online in accordance with publisher policies. Please scroll down to view the document itself. Please refer to the repository record for this item and our policy information available from the repository home page for further information.

To see the final version of this paper please visit the publisher's website. Access to the published version may require a subscription.

Author(s): Anne Gerritsen

Article Title: From Demon to Deity: Kang Wang in Thirteenth-Century Jizhou and Beyond

Year of publication: 2004

Link to published version: http://dx.doi.org/10.1163/1568532042523158

Publisher statement: None 


\title{
From Demon to Deity: Kang Wang 康王 in Thirteenth-Century Jizhou 吉州 and Beyond*
}

\author{
Anne Gerritsen \\ University of Warwick
}

Running header:

From Demon to Deity: Kang Wang in Jizhou

Abstract:

This essay discusses the cult of a deity known as Kang Wang, worshipped throughout Jizhou in thirteenth-century Jiangxi. The identity of this deity remains to some extent mysterious; many different identifying stories for Kang Wang coexist. Underneath these guises, however, his origins as a fearsome and unnamed demon shine through. I argue that the various representations of Kang Wang must be understood as resulting from the very different agendas of the authors who created those identities, but they all share one aim: covering up the demonic roots of the deity. Providing a name and place of origin for the deity should be seen as attempts to exert authority over this demonic force.

\footnotetext{
* I gratefully acknowledge the support from the British Academy in carrying out research in Jiangxi. Professor Liang Hongsheng 梁洪生, Museum Director Gao Liren 高立人, and Wu Wei 吴薇 were instrumental in Ji'an. I thank Professors Peter Bol, Stephan Feuchtwang, Barend ter Haar, Paul Katz and John Lagerwey for helpful suggestions and comments on earlier versions of this paper. All remaining errors are, of course, my own.
} 
Introduction

The god known as the Awesomely Manifest, Good and Beneficial, Efficaciously Responsive, Heroically Martyred King (weixian shanli lingying yinglie wang 威顯善利靈應英烈王), of the imperially sanctioned Numinous Assistance Temple, has as surname Kang 康, and his honorary name was Baoyi 保裔.

With this confident assertion, a thirteenth-century literatus from Luling 盧陵 identified a local deity, Kang Wang, worshipped for his beneficial powers, as Kang Baoyi. A few decades later, a Daoist master wrote a text which featured a deity named Kang Wang, entitled Awesomely Helpful, Good and Beneficial, of Broad Kindness, Heroically Martyred King (weiji shanli fuhui yinglie wang 威濟善利孚惠英 烈王). But this Kang Wang is a very different character. “This demon (gui 鬼) has spread poison in this area since last year. If we had not become aware of what he was doing, then two out of every three people in Guozhou would have died." ${ }^{2}$ Different stories identifying this deity coexisted in thirteenth-century Jizhou. Some praised his protective powers, while others condemned the harm he had done. In today's Luling, now known as Ji'an 吉安 in southwest Jiangxi 江西, one can still find temples for Kang Wang, and the written records for the area would suggest Kang Wang worship never disappeared. Despite this impressive continuum, conflicting identities also continue to coexist until today. ${ }^{3}$

\footnotetext{
${ }^{1}$ Ouyang Shoudao 欧阳守道, Xunzhai wenji 巽斋文集 (Siku quanshu edition), 16.1a.

${ }^{2}$ Daozang (1607, reprint ed. Taibei, 1962) 18.95.

${ }^{3}$ See Anne Gerritsen, 'A Thirteenth-Century Cult in the Villages of Ji' an (Jiangxi), or 'Fieldwork for Historians', Journal of Sung Yuan Studies 33 (2003):181-185.
} 
Of course recent work has shown the coexistence of different myths to be nothing out of the ordinary. Prasenjit Duara published a pathbreaking study of the myth of Guandi in 1988, which analysed the significance of the 'amazing variety of interpretations of the Guandi myth.' $\quad$ Robert Hymes' recent book, Way and Byway, shows that gods appear in different guises, depending on who is doing the representing and in what context. ${ }^{5}$ Paul Katz' work, both his 1995 Demon Hordes and Burning Boats and his 1999 Images of the Immortal, is also concerned with different representations of gods and immortals. ${ }^{6}$ Significantly, the variety of representations noted by Duara, Hymes and Katz never obscures the identity of the heroes at the heart of their cults, however different the various Guandis, Marshal Wens, and Lü Dongbins are. With the cult of Kang Wang, we are never quite sure who we are dealing with. The lack of a convincing single identity is revealing. Through the thin veil of Kang Wang's different guises, his origins as a fearsome demon shine through. Giving this fear-inspiring force a proper name, a place of origin, and a 'work unit', I argue, should be understood as ways of attempting to exert authority over an otherwise uncontrolled demonic force. Knowing the name of a demon, listing it in a register, and even depicting it are important elements of subduing a demon, as Anna Seidel pointed out as far back as 1983. ${ }^{7}$ The different guises in which Kang Wang is represented in the sources must therefore be understood as resulting from the different motivations of the

\footnotetext{
${ }^{4}$ Prasenjit Duara, 'Superscribing Symbols: The Myth of Guandi, Chinese God of War' Journal of Asian Studies 47.4 (1988):780.

${ }^{5}$ Robert Hymes, Way and Byway: Taoism, Local Religion, and Models of Divinity in Sung and Modern China (Berkeley and Los Angeles: University of California Press, 2002).

${ }^{6}$ Paul R. Katz, Demon Hordes and Burning Boats: The Cult of Marshal Wen in Late Imperial Chekiang (Albany: State University of New York Press, 1995) and Images of the Immortal: The Cult of Lü Dongbin at the Palace of Eternal Joy (Honolulu: University of Hawai'i Press, 1999).

${ }^{7}$ Anna Seidel, 'Imperial Treasures and Taoist Sacraments; Taoist Roots in the Apocrypha' in Tantric and Taoist Studies in Honour of R.A. Stein, vol II, Mélanges chinois et bouddhiques XXI (1983), especially 320-332.
} 
authors of the various Kang Wang stories behind those identities, and the different social and cultural contexts in which such identities were established. Creating identities for Kang Wang, I will argue, was part of an ongoing process by which the fear inspired by Kang Wang was neutralised and exorcised.

This essay begins not with a history of the cult of Kang Wang, but with an analysis of the different Kang Wang stories that circulated in the thirteenth century. The many different Kang Wangs make it difficult to determine who this god is, as both Qing evidential scholars and contemporary anthropologists agree, but analysis of these different stories shows that despite the outwardly different representations, the stories share one significant characteristic: Kang Wang inspired fear. All of the Kang Wang stories suggest that for the majority of Kang Wang's followers, the element in his identity that mattered was his awesome power, which filled them with fear. Looking closely at the process of identifying Kang Wang, and asking who is doing the identifying, in which context and with what motivations, reveals that the various interpretations could all be read as attempts to replace an identity considered unsuitable with another, more 'acceptable' identity.

The first story: Kang Baoyi (?-1000)

In the decades after the establishment of the Song dynasty in 960, the first Song emperor, Taizu (r. 960-976), came to rely heavily on a general by the name of Kang Baoyi. Kang Baoyi was the son of Kang Zaiyu 康再遇, a general who had also served Taizu and had died in battle in the Taixing Mountains 太行山 between the northern circuits of Hedong and Hebei. Before him, Kang Baoyi’s grandfather had also died on the battlefield during the Zhangxing reign period (930-934). Kang Baoyi 
was a morally upstanding man: fond of ritual and respectful of scholars ( $r u$ 儒). $\mathrm{He}$ served in Taizu's military campaigns for many years, and when Zhenzong came to the throne in 998, Kang was granted permission to return home and care for his elderly mother.

His peace did not last long; the Khitan invaded in the third year of the Xianping reign period (1000), and Kang Baoyi was sent north to defend the Gaoyang Pass 高陽 關 in today’s Hebei. When the commander, Fan Tingzhao 范廷召 (927-1001), requested assistance from the battlefield, Kang Baoyi led his troops to face the Khitan. ${ }^{8}$ Dusk had already fallen, and fighting was suspended until the next morning. When dawn arrived, Fan Tingzhao had fled, and Kang was entirely surrounded by the enemy. Kang's aides tried to persuade Kang to lay down his arms and escape, but Kang spoke the following words: 'When facing danger, one cannot escape it. I am ready to give my life.' With a deep sigh he took up his arms and entered battle, killing and injuring many, using his bare fists after his arrows were finished. There Kang died, in the battlefield, as his father and grandfather had done before him.

The emperor was deeply moved when Kang's death became known at court. He posthumously bestowed on Kang the rank of palace attendant (侍中), and Kang's mother, still alive at the age of 84 sui, was honoured with the title 'Imperial Lady of Chen’陳國太夫人. Kang’s wife, a Ms Xue 薛, who had died earlier, also received an honorary title (Lady of Hedong 河東郡夫人), as did Kang’s sons. ${ }^{9} \quad$ Recognition of his service to the Song did not end with his death; the court enfeoffed Kang's spirit

\footnotetext{
${ }^{8}$ For Fan Tingzhao’s biography, see Tuotuo, comp., Song shi 宋史 (1343-1345, reprint ed. Beijing, 1977) 289, pp. 9697-9699.

${ }^{9}$ For Kang Baoyi’s biography, see Song shi 446, pp. 13150-13152.
} 
first as duke (gong 公), then as king (wang 王), and between 1119 and 1227 his spirit received a total of eight honorary titles. ${ }^{10}$ His courageous battle against foreign invaders made him eminently suitable for enfeoffment by the embattled Southern Song court. As Li Xianzhang 李献璋 has shown, such tutelary and martial deities were called upon in the fight against invading forces by conferring honourary titles upon them. $^{11}$

Although these titles demonstrate that the spirit of Kang Baoyi was officially recognised throughout the twelfth century, the oldest extant evidence of the existence of a temple dedicated to Kang Baoyi dates from the first half of the thirteenth century. ${ }^{12}$ Kang's spirit had provided assistance in local skirmishes with bandits in three counties—Jishui 吉水, Yongfeng 永豐 and Anfu 安富—in the south-west of Jiangnanxi circuit (in Jizhou 吉州 in present day Jiangxi province). In gratitude, the local scholar Yang Zhangru 楊長孺, son of the famous Southern Song poet Yang

\footnotetext{
${ }^{10}$ Kang Baoyi's final title was Awesomely Manifest, Good and Beneficial, Efficaciously Responsive, Heroically Martyred King (weixian shanli lingying yinglie wang). Ouyang Shoudao, Xunzhai wenji, 16.1a. The title is also mentioned by Yang Zhangru 杨长孺 in his 'Inscription for the Kang Wang Temple'. Jishui xianzhi 吉水县志 (1875), 12.23a-b. Eight characters is the maximum number of characters in an imperially bestowed title. See Valerie Hansen, Changing Gods in Medieval China, 1127-1276 (Princeton: Princeton University Press, 1990), p. 82.

${ }^{11}$ Li Xianzhang 李献璋, Maso no shinkō no kenkyū 妈祖信仰 研究 [Studies on the belief of Mazu] (1979), especially 214-216.

${ }^{12}$ According to the 1332 gazetteer for Zhenjiang 镇江 prefecture, there was a Kang Wang shrine in the western wing of the Chenghuang Temple in Zhenjiang. 'It was built by Ai Qinwen 艾欽文 from this prefecture in the renwu year of Shaoxing [1162].' The fourteenth-century narrative provides some background. Apparently, twelfth-century Zhenjiang had been hit by a serious epidemic. The local doctor, Ai Qinwen, then had a dream in which a deity gave him a fragrant herb potion to drink. Ai then put herbs in his burner and prepared a potion in his courtyard. He gave this potion to all the patients who visited him, and all were healed. Ai subsequently donated his own funds to build a shrine in the west wing of the Chenghuang temple. Many years later, in 1319, the temple was destroyed. With the temple's roof tiles down, beams rotten, and the statue of the god on the ground, people found a small volume inside the belly of the statue. It turned out to be a small medical handbook belonging to the original founder of the temple, Ai Qinwen. The statue was restored in 1329 with the help of a descendent of $\mathrm{Ai}$, and when the statue was finally erected again, it was said to have smiled serenely. In Ai Qinwen's own story, however, there are no elements that identify him as Kang Baoyi. Further comments provide Kang's official titles, and the biographical details about Kang Baoyi. It is unclear,
} 
Wanli 楊萬里 (1127-1206) who hailed from Jishui, wrote an inscription for the Jishui Kang Wang temple. ${ }^{13}$ 'Worship for this god has spread to Jiang 江, Huai 淮, Min 闽 and Zhe 浙', Yang writes, 'where he is both manifest and efficacious, while the numbers of worshippers never cease. ${ }^{14}$ According to Yang, then, by the midthirteenth century the cult of Kang Baoyi had spread throughout the seven most populated circuits of Southern Song China.

Yang Zhangru was not alone in noting Kang's worship. The famous scholar Ouyang Shoudao 歐陽守道 (1209-?), head of the renowned Bailuzhou Academy 白 鷺洲書院 in Luling, just south of Jishui, where the Song martyr Wen Tianxiang 文天 祥 was among his students, wrote an inscription for a local Kang Wang temple in 1248. 'The counties of Luling [i.e. Jizhou] all have branch temples for [Kang] Wang,' writes Ouyang Shoudao, 'scholars and commoners from far and near congregate here regularly.' ${ }^{16}$ The prefectural magistrate in Luling prayed successfully for rain at the Kang Wang temple in the same year, and in Poyang, further to the north

\footnotetext{
however, whether this shrine, when it was built, was identified as a shrine for Kang Baoyi. Yu Xilu 俞 希魯, comp., Zhishun Zhenjiang zhi 至順鎮江志 (1332, reprint ed. Taibei, 1981), pp. 255-6.

${ }^{13}$ Yang Zhangru's biography is included in the Jishui gazetteer. Although his exact birth and death dates are unknown, his biography suggests that he was born in the 1150s, and died at the age of 80 in the 1230s. Jishui xianzhi, 34.13a-14a. Yang Zhangru's father was the famous poet and scholar Yang Wanli 杨万里 (1127-1206). For his biography, see Herbert Franke, Sung Biographies (Wiesbaden: Steiner Verlag, 1976), pp. 1238-1245.

${ }^{14}$ Jishui xianzhi, 12.23b.

${ }^{15}$ Ouyang Shoudao passed the jinshi exam in 1241. He held appointments in Ganzhou 赣州 as registrar and assistant head of the Yuelu 获麓 Academy in Changsha, Hunan, where he met Wu Ziliang 吳子良 (1197-?). He held several posts at the imperial library in the capital (Hangzhou). See the biography of Ouyang Shoudao, Song shi 411, pp. 12364-12367. The Bailuzhou Academy in Luling was established in 1241 by the famous Southern Song minister and Ouyang Shoudao's patron Jiang Wanli 江万里 (1198-1275). On Bailuzhou Academy, see John Meskill, Academies in Ming China: An Historical Essay (Tucson: University of Arizona Press, 1982), p. 14 and Linda Walton, Academies and Society in Southern Sung China (Honolulu: University of Hawai'i Press, 1999). On Jiang Wanli, see Franke, Sung Biographies, pp.207-209.

${ }^{16}$ Ouyang, Xunzhai wenji, 16.2b.
} 
in Jiangxi, a Kang Wang temple was built in the same decade. ${ }^{17}$ In Jingdezhen 景德 镇 in northern Jiangxi, a Kang Wang temple was said to have existed since $1225 .^{18}$ Even though little evidence remains today to support Yang Zhangru's claim that Kang Baoyi was worshipped throughout Huainan, Zhedong and Zhexi, Jiangdong and Jiangxi, and Fujian, there is little doubt that Kang Wang temples dotted the landscape in thirteenth-century Luling.

If the popularity of the cult was at its height in the thirteenth century, it never completely disappeared throughout the centuries that followed. In 1329, a temple for Kang Baoyi in Zhenjiang 鎮江, due east of Nanjing, was restored a decade after the buildings had been destroyed in $1319 .{ }^{19}$ In the fourteenth century, Kang Wang temples were being built or restored throughout Jiangxi. ${ }^{20}$ The remaining records of the fifteenth and sixteenth centuries would suggest that Kang Wang temples may have started to lose followers, but during the seventeenth century, the temples flourished again. $^{21}$ Linjiang 臨江 prefecture in Jiangxi, for example, boasted three temples for Kang Baoyi in 1668, and Xinyu 新喻 county, one of the counties of Linjiang

\footnotetext{
${ }^{17}$ Luling xianzhi 卢陵县志 (1825), 9.12b-13a. Evidence for the temple in Poyang comes from an 1748 inscription for a Kang Wang temple in Poyang 鄱阳, said to have existed there for five hundred years. Poyang xianzhi 鄱阳县志 (1871) 4.19b-20a.

${ }^{18} \mathrm{Yu}$ Xilu, comp., Zhishun Zhenjiang zhi, p. 256.

${ }^{19}$ Yu Xilu, comp., Zhishun Zhenjiang zhi, pp. 255-256.

${ }^{20}$ The Jiangxi tongzhi 江西通志 mentions the restoration of a temple for Kang Baoyi during Hongwu (1368-1398) in Ruizhou prefecture in Jiangxi. Jiangxi tongzhi (1732), juan 108. The scholar-official Liang Qian 梁潜 (1366-1418) wrote an inscription for the Kang Wang temple at Baisha near Luling. See Liang Qian, Bo'an ji 泊庵集 (Siku quanshu edition), 3.29b-31a.

${ }^{21}$ The only references to Kang Wang temples in the fifteenth and sixteenth centuries I have found are the following. In Lianjiang 連江 County in Fujian a Kang Wang temple was restored during Yongle (1403-1424). Lianjiang xianzhi 連江縣志 (1989), p. 342. One Kang Wang temple is mentioned in the 1461 Da Ming yi tong zhi 大明一通志 (juan 56). For the sixteenth century, I found only two references to Kang Wang temples: one in the Zhengde period (1506-1521) gazetteer for Raozhou 饶州 prefecture in Jiangxi ([Zhengde] Raozhou fuzhi [正德] 饶州府志 (1506-1522) 3.63a), and one in the gazetteer for Linjiang prefecture in Jiangxi (Linjiang fuzhi 临江府志 (1536) 8.7b).
} 
prefecture, alone had no less than seven temples for Kang in $1673 .^{22}$ Kang Wang worship was not restricted to Jiangxi; the early Qing scholar-official Tian Wen 田雯 (1635-1704), who hailed from Shandong, came across worship of Kang Baoyi in Guizhou 貴州, where he served from 1688 as governor. ${ }^{23}$ In the eighteenth century there were Kang Wang temples throughout Jiangxi and Fujian, and by the nineteenth century, almost every county gazetteer for Ji'an prefecture listed one, sometimes several, Kang Wang temples. ${ }^{24}$

Despite the traumatic events of the twentieth century, when many temples were destroyed or put to different uses, worship of Kang Baoyi still exists today. In Baisha 白沙, a village on the river Gan 贑 just north of what is today Ji'an Municipality 吉 安市 in Jiangxi, the Lingyou Temple 靈祐廟 was restored in 1998. Inside are statues of Guanyin 观音, the Dark Emperor 玄帝, Baxianwang 八賢王, and the god of wealth 財神, but the main statue of the temple is an enormous, black-faced Kang Wang. ${ }^{25}$ The guard of the temple, a man in his mid-forties, claimed to be the latest descendent in an unbroken line of at least twenty generations of temple guards, and assured me that this temple was the same as the Baisha Lingyou Temple for Kang

\footnotetext{
${ }^{22}$ Kang Wang temples in Linjiang are listed in Linjiang fuzhi (1668) 8.8b and 8.13b. The seven Kang Wang temples in Xinyu 新喻 county are listed in Xinyu xianzhi 新喻县志 (1673) 8.12b.

${ }^{23}$ Tian Wen 田雯 (1635-1704), ‘Nan Zhai Yun Kang Baoyi’ 南斋云康保裔 in Qianshu 黔書, included in Guhuantang ji 古欢堂集 (Siku quanshu edition), juan 39. On Tian Wen, see Arthur W. Hummel, ed., Eminent Chinese of the Ch'ing Period (Washington: Government Printing Office, 194344), p. 719.

${ }^{24}$ The 1732 provincial gazetteer for Jiangxi lists temples for Kang Baoyi in several prefectures. See Jiangxi tongzhi 江西通志 (1732), juan 108. The 1737 Fujian provincial gazetteer lists a Kang Wang temple in Fuqing 福清 county. See Fujian tongzhi 福建通志 (1737), juan 15. Several eighteenthcentury county gazetteers from this area also mention Kang Wang temples. For examples of Kang Wang temples listed in nineteenth-century county gazetteers, see Xinyu xianzhi 新喻县志 (1825), 5.25b; Fenyi xianzhi 分宜县志 (1871) 2.55b; Luling xianzhi (1873) 45.33b; Longquan xianzhi 龙泉县 志 (1873) 3.6a; Yongning xianzhi 永宁县志 (1874) 2.12a-b; Yongfeng xianzhi 永丰县志 (1874) 8.7b; Jishui xianzhi (1875) 12.22b.
} 
Wang commemorated by the late fourteenth-century, early fifteenth-century scholarofficial Liang Qian 梁潛 $(1366-1418){ }^{26}$

Of course Kang Baoyi's story is by no means exceptional. Throughout the history of imperial China military men, like civil servants, died in the service of their emperors, and received posthumous recognition for their loyalty and bravery. Deceased scholars and military figures alike continued to be recognised after their deaths in shrines for worthies and temples for local gods. The Song court was particularly active in seeking out local worthies and deities. As Valerie Hansen has shown, the Southern Song court used complex bureaucratic procedures before awarding enfeoffments and honorary titles to a wide variety of gods, including those who had shown military prowess during their lifetimes. ${ }^{27}$ Kang Baoyi received his first honorary title during the Xining reign period (1068-1078) of the Northern Song, and his temples continued to receive recognition from Huizong's reign (1101-1126) onwards. $^{28}$

Not only is the way in which Kang Baoyi's status as a deity becomes officially recognised a familiar one, but also the type of god Kang Wang is. Temple inscriptions celebrate his responsiveness (ying 應) to worshippers' requests, gazetteers praise his efficacy in times of droughts, floods, and infectious diseases. In many

\footnotetext{
${ }^{25}$ For a brief account of my visit to this temple, see Gerritsen, 'A Thirteenth-Century Cult in the Villages of Ji'an (Jiangxi)'.

${ }^{26}$ Liang Qian, Bo'an ji, 3.29b-31a.

${ }^{27}$ Hansen, Changing Gods, pp. 79-104. Robert Hymes' 2002 study of Song dynasty Daoism and local religion suggests the enfeoffment policies of the Song government await further study. Hymes, Way and Byway, p. 104.

${ }^{28}$ The text reads 'Traces of his spirit (ling) were manifest in Yiyang 七陽 in Xinzhou 信州. During Xining [1068-1078] he was enfeoffed as Heroic and Manifest Lord 英顯侯.' See Yu Xilu, [Zhishun] Zhenjiang zhi, p. 256. As Hansen has shown, vast numbers of gods were enfeoffed from about 1075 onwards. Hansen, Changing Gods, p. 79. Hymes works out that between 1075 and 1126, the state officially recognised 11,989 deities, or .77 gods per prefecture per year. Hymes, Way and Byway, p. 303.
} 
ways, the Kang Wang described in such texts fits Robert Hymes' 'personal model': Kang Wang is an 'extraordinary person' rather than an office-holder in a divine bureaucracy, humans have direct contact with him, rather than approaching him with the assistance of a religious professional, and Kang Wang's authority is 'inherent in the person of the god, rather than delegated'. ${ }^{29}$

A general dies selflessly and heroically on the battlefield on the northern border; after his death his spirit appears in the south; he receives official recognition by the Song government, after which his worship continues into the twenty-first century. There might seem to be little scope for different interpretations or representations of Kang Wang. Yet, like in the case of Duara's Guandi or Katz' Marshal Wen, radically different versions of the hagiography of Kang Wang coexisted. ${ }^{30}$ Next to the god Kang's identification as the spirit of General Kang Baoyi, a quite different identity also circulated in the thirteenth century.

\section{The Second Story: Kang Wang Defeated by Marshal Wen}

The hagiography of Wen Qiong 溫瓊 or Marshal Wen features a Kang Wang with the honorary title of Awesomely Helpful, Good and Beneficial, of Broad Kindness, Heroically Martyred King (weiji shanli fuhui yinglie wang. The surname and the (almost) identical honorary title would suggest this is the same Kang Wang as the spirit

\footnotetext{
${ }^{29}$ Hymes, Way and Byway, pp. 4-5. The idea that there are at least two models of divinity in Song religion, a bureaucratic model and a personal model, is one of the arguments developed throughout Hymes' book.

${ }^{30}$ Katz refers to the phenomenon of the coexistence of different myths as 'cogeneration'. Katz, Demon Hordes, pp. 113-116. Katz' 'cogeneration' is different from Duara's concept of 'superscription' where different cultural actors add new layers to previously current interpretations of a deity. See Duara, 'Superscribing Symbols', pp. 778-95. Hymes' view is slightly different again. He suggests that, despite the possibility of the coexistence of 'utterly alternative versions,' previous interpretations 'put bounds to the interpretations that come after'. Hymes, Way and Byway, p. 325.
} 
of Kang Baoyi. ${ }^{31}$ This Kang Wang, however, is not identified as the spirit of Kang Baoyi at all, nor does he operate as the protective spirit who frightens away bandits and brings rain to the area that featured in the account of Kang Baoyi's deification. The hagiography, entitled 'Biography of Grand Guardian Wen, Supreme Commander of Earth Spirits’ 地祇上將溫太保傳, was written by a Daoist master by the name of Huang Gongjin 黃公瑾 in 1274, only 26 years after Ouyang Shoudao's inscription for the Jishui Kang Wang temple. ${ }^{32}$ As Paul Katz points out, Huang's hagiography of Wen is largely concerned with narrating Wen's encounters with and victories over various cults considered 'heterodox' in the Daoist tradition. One of these encounters is with Kang Wang.

Wang Qingru 王卿孺 from Chenzhou 辰州 was appointed as magistrate of Guozhou 果州. One day he came by the old temple of Chenxi 辰溪古寺. He saw that the two characters wensi 瘟司 [Plague Department] were written over the entrance of the hall on the right. Qingru stared at this, and, forgetting proper form, walked up to the hall, pulled open the curtain and entered.

Suddenly a man appeared who looked like a servant from the [outside] world. Approaching, he greeted Qingru, and said: 'The Great King has an order (ming

\footnotetext{
${ }^{31}$ Seven of the eight characters of the honorary title listed here are identical to the characters listed in Yang Zhangru's inscription. According to Yang, Kang Wang had received the characters weiji shanli fuying yinglie 威濟善利孚應英烈 by the Qingyuan reign period [1195-1200]. The title was later beautified to read weixian shanli lingying yinglie 威顯善利靈應英烈, which is the honorary title listed in Ouyang Shoudao's inscription. See Jishui xianzhi (1875) 12.23a-b. Since the hagiography was completed in 1274 , it is conceivable that this section of the hagiography was based on an older source. See below for further discussion of this point.

${ }^{32}$ Huang Gongjin 黄公瑾, 'Biography of Grand Guardian Wen, Supreme Commander of Earth Spirits' (Diqi shangjiang Wen Taibao zhuan 地祇上將溫太保傳) in Daozang (1607, reprint ed. Taibei, 1962) 18.90-96. The text is listed as number 557 in Kristofer Schipper's Concordance du Tao-tsang (Paris: Publications de l'École Française d'Extrême Orient, 1975). The translation of the title derives from Katz, Demon Hordes, p. 80. Katz's discussion of Marshal Wen's hagiography in the Daozang is on pp. 80-88.
} 
命). Please placate [the person] you will meet.' Qingru was very surprised, and said: 'Who is the King?' [The man] answered: 'He is Kang Wang. His imperially decreed title is Awesomely Helpful, Good and Beneficial, of Broad Kindness, Heroically Martyred King. ${ }^{33}$

After this somewhat mystifying introduction, in which a local government official, Wang Qingru, receives an order from a deity he does not know, Wang Qingru meets Kang Wang himself, who speaks the following words to him:

I serve the [God of] Walls and Moats of the capital. I have been put in charge of the Plague Department, where I investigate good and evil. It has been my destiny to meet you, so that we can settle [this matter]. It so happens that now that Your Highness the administrator has arrived, I need to attend to some matters. [Running the risk of] insulting your awe-inspiring authority, I hope that your exalted highness would deign to accept this task. ${ }^{34}$

Kang Wang's attempts to convince Wang Qingru with this obsequious language are initially not successful, as Wang Qingru demands further information. Kang Wang, it transpires, wishes to enlist Wang Qingru's help in subjugating a certain Perfected Being Zhong (Zhong zhenren 鍾真人). Presenting himself as the incumbent in charge of plague management, complete with the official charms and certificates (fudie 符牒) bestowed on him by the God of Walls and Moats, and boasting success against plagues as well as false beliefs, Kang Wang clearly perceives Perfected Being Zhong as a threat. Not only does Zhong allegedly interfere with Kang's campaigns against epidemics, but according to Kang, Zhong also spreads the rumour that Kang Wang

\footnotetext{
${ }^{33}$ Daozang 18.94.

${ }^{34}$ Daozang 18.94.
} 
spreads plagues so as to gain more followers. Wang Qingru, understandably, wishes to know why Perfected Being Zhong poses a threat to Kang Wang, if he was otherwise so successful. Kang Wang answers: allege

There are three matters against which I cannot compete. One: his surname and given name are written over the top of the building on the right. Two: he is capable of captoptromancy [i.e. the technique of calling up a god by using a mirror $]^{35}$. Three: he considers Metropolitan Inspector Wen of Dongyue 東獄 as his servant, and makes him obey his orders. Not one of the godly temples of the realm dares to go against him. ${ }^{36}$

When Wang Qingru remains unimpressed, Kang Wang gives him 500 taels of silver, in a desperate attempt to look powerful. Wang Qingru then seeks out Perfected Being Zhong, who explains: 'This demon has spread poison in this area since last year. If we had not become aware of what he was doing, then two out of every three people in Guozhou would have died.' Kang Wang's crimes are especially serious since he held the post of Grand Guardian (taibao 太保) in the court of Dongyue, and was one of the ten Earth Spirits (diqi 地祇). ${ }^{37}$ Despite Wang Qingru's request to forgive Kang Wang, both Kang Wang and his servant are rounded up, and dealt one hundred blows by Wen Qiong.

Who is Kang Wang?

${ }^{35}$ Katz, Demon Hordes, p. 84 . On the use of mirrors in rituals (captoptromancy), see Michel Strickmann (edited by Bernard Faure), Chinese Magical Medicine (Stanford: Stanford University Press), p. 125 , p. 207, p. 239 etc.

${ }^{36}$ Daozang 18.94.

${ }^{37}$ Daozang 18.94. The position of Earth Spirit had been bestowed upon him by Heavenly Master Xujing 虚靖. Xujing is the $30^{\text {th }}$ Heavenly Master Zhang Jixian 張繼先 (1092-1126), who had also promoted Wen Qiong to the rank of Earth Spirit. Katz, Demon Hordes, p. 84. 
The Kang Wang in Marshal Wen's hagiography quite clearly is a different Kang Wang from the spirit of Kang Baoyi. The difference between the personal protector of Ouyang Shoudao and Yang Zhangru's temple inscriptions, and this pretender in the plague bureaucracy cannot simply be explained in terms of Hymes' personal and bureaucratic models of divinity. Of course a deity acting as a personal benefactor in one source can appear in a Daoist source such as Wen Qiong's hagiography as a member of the divine hierarchy, in this case as one of the ten Earth Spirits, one of Dongyue's ten Grand Guardians. This Kang Wang, however, is a rogue spirit, a plague-spreading demon, subjugated by Wen Qiong. These are 'wildly divergent perceptions' indeed! $!^{38}$

Neither did Kang Wang's multiple identities go unnoticed. When the Qing

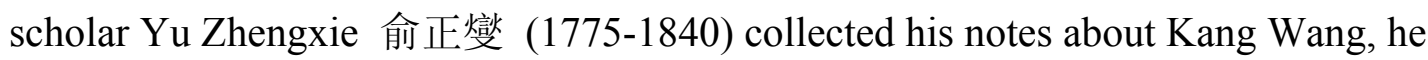
began by writing about Kang Baoyi's life and heroic death, and listing the many temples where Kang Baoyi was worshipped. ${ }^{39}$ But as his research progressed, he encountered references to other Kang Wangs. Some Kang Wangs were identified as King Kang of the Zhou dynasty, others as King Kang of Chu or King Kang of the Song. In Jiexiu 介休 County in Shanxi, he found a Kang Wang temple where Kang Shen 深, taiwei 太尉 of the Tang was worshipped. In the end, Yu Zhengxie concludes: 'His name is Kang Wang. I do not know which god this is. ${ }^{40}$ Others come to similar conclusions. The compilation entitled 'Remaining Stories about

\footnotetext{
${ }^{38}$ Katz, Demon Hordes, p. 87.

${ }^{39} \mathrm{Yu}$ Zhengxie became a juren in 1821 , but never passed the jinshi exam. He worked in the staff of several high officials, amongst them Lin Zexu 林则徐 (1785-1850), the governor-general of Hubei and Hunan. His notes on Kang Wang appear in Guisi cungao 癸已存稿, which also contains a wealth of other information on a wide range of topics. Hucker, ed., Eminent Chinese, pp. 936-7.

${ }^{40} \mathrm{Yu}$ Zhengxie, 'The God Kang Wang' ('Kang Wang shen’ 康王神), Guisi cungao, 13.409.
} 
Cauldron Casting' (Zhuding yuwen 鑄鼎餘聞) merely collects quotes about Kang

Wang. These quotes range from a reference to the Kang Wang of Dongyue's retinue found in Wu Zimu’s 吳自牧 late thirteenth-century Menglianglu 夢梁錄 to references to place names of sites in the Lu Mountains 盧山 in northern Jiangxi where King Kang of the Zhou went on an inspection tour found in a Qing dynasty archaeological study of Jiangxi, but the text makes no attempt to formulate a definitive statement about Kang's identity. ${ }^{41}$ As Yu Yue 俞杫 (1821-1906), author of Chaxiangshixuchao 茶香室續鈔 writes, 'In the end we do not know who Kang Wang is. $^{, 42}$

The god referred to as Kang Wang appears in the writings by authors of a variety of persuasions in very different guises. For some he is General Kang Baoyi, for others, Kang Wang the plague-spreading demon, yet others see him as Kang Wang of Dongue's retinue or King Kang of the Zhou. This brings to the fore an interesting question. What does it mean that we know Kang Wang in such divergent guises? Of course representations of deities change over time, and depend on who is doing the representing, but let us assume, as Hymes does, that we can treat a god as 'an independently determining element' ${ }^{43}$ In other words, we take as our starting point that there is more to 'a god' than his or her representation, merely dependent on the

\footnotetext{
${ }^{41}$ Zhuding yuwen 鑄鼎余聞 (1899, reprinted in Zhongguo minjian ziliao huibian 20, Taibei, 1989), pp. 155-158.

${ }^{42}$ Chaxiangshi xuchao 茶香室續鈔, juan 19, quoted in Lü Zongli 呂宗力, Zhongguo minjian zhushen 中國民間諸神 (Taiwan: Taiwan xuesheng, 1991), p. 701-2. On Yu Yue, see Hucker, ed., Eminent Chinese, pp. 944. There is no less confusion about the identity of Kang Wang among contemporary anthropologists. Zhang Sijie, who carried out fieldwork between 1996 and 1997 in the Hakka communities of Ganzhou, in the Ji'an-Ganzhou border area, notes down the many different answers provided by his informants in answer to his questions over the identity of the Kang Wang widely worshipped in this area. Zhang Sijie 張嗣介, 'Ganzhou Kang Wang chongbai 贑州康王崇拜' in Gannan miaohui yu minsu 贛南廟會與民俗 vol. 7, especially pp. 108-111.

${ }^{43}$ Hymes, Way and Byway, p. 268.
} 
representer and the context in which the representation occurs. What determines a god's representation must include, apart from representer and context, also the god himself, or rather, what worshippers would recognise as a god's determining element. It is this determining element, which makes Kang Wang recognisable as Kang Wang, that we need to seek out.

\section{Fear for Kang Wang in Temple Inscriptions}

While Kang Wang may initially seem to have too many divergent identities to enable us to find the shared element, there is one aspect that appears in almost every description of Kang Wang's activities. That aspect is the fear he inspires in his followers. In whichever capacity Kang Wang appears, his awesomeness inspires fear; whoever describes Kang Wang recognises the fear he spreads. The Luling scholar Ouyang Shoudao devotes much of his 1248 inscription for the Jishui Kang Wang temple to a discussion of what he considers to be the fear Kang Wang instils in his followers.

The counties of Luling all have branch temples for [Kang] Wang. Commoners and gentlemen from far and near congregate here regularly, and no one dares to be negligent. However, in serving the god, the [followers] are frequently motivated by fear rather than by respect. Every day there are new fabrications and lies are further embellished, especially those relating to his control over epidemics. He is adorned with honorary titles, but no one remembers the [events of] [Kang] Wang's lifetime. ${ }^{44}$

\footnotetext{
${ }^{44}$ Ouyang, Xunzhai wenji, 16.2b.
} 
Ouyang's entire purpose in writing this text is encapsulated in these last words. He wishes to persuade his audience that worship inspired by fear for the god's powers is wrong. Instead, Ouyang suggests, worship should be grounded in a respect for the values embodied by General Kang Baoyi in his lifetime.

Interestingly, in his attempts to convince his readers, Ouyang reveals much about the nature of the worship he rejects.

Spirit-mediums (wugui 巫鬼) of [the area] south of the river have long carried out their practices. [Kang] Wang is doubly unfortunate as he is classified among the likes of [the plague-spreading demon] Boqiang 伯強 because of his awe-inspiring and incorruptible steadfastness. The various sacrifices have become corrupted and too casual. If there is no powerful smell of incense, then there are those who wear a cangue and red clothing, and imprison themselves. The spirit-medium wields his power, forbidding others to speak of him. If someone dares to say one word, proving that their principles are false, then all those associated with the medium will make that person deeply frightened of them, as if calamities are about to happen. How could one blame these people for the god's desire to inspire awe in this fashion? Seeking to understand the reasons for [this behaviour], it would seem that learned gentlemen without any investigation adhere to the records of the magician (fang $c e$ 方冊) when reciting [the story of] the life of [Kang] Wang. As a consequence, ignorant common people are frightened by the legends and fabrications, which no one can put a stop to. ${ }^{45}$

\footnotetext{
${ }^{45}$ Ouyang, Xunzhai wenji, $16.2 \mathrm{~b}$.
} 
The practice Ouyang condemns here is what scholars like Edward Davis and Michel Strickmann have referred to as shamanism, or spirit possession, or ecstatic religion. ${ }^{46}$ Such practices, widespread throughout China, revolved around the village spiritmedium. The god would enter the medium's body or the medium would travel to the world of the spirits, while rituals with loud drumming, frenzied dancing, and offerings of meat were performed. ${ }^{47}$ The use of the village spirit-medium for dealing with illness and disasters was, as Davis' study has shown, widespread in Southern Song China. Ouyang's condemnation centres on the spirit-medium. By instilling fear, the spirit-medium can wield his or her powers. Fear determines relations between village medium and villagers, between the god and his believers. In Ouyang's eyes, fear is the most destructive force of the god. Hence his aim in writing this text; instead of a relationship determined by fear, Ouyang attempts to create a relationship between believers and god based on admiration for the morals embedded in Kang Baoyi’s life.

Quoting the Yijing, Ouyang goes on to discuss the transition from life to death, stressing the constancy between the two. Kang Baoyi's body might have perished in battle, but he continues to 'exist' as filial son in his family, as loyal minister in the state. From his lofty perch, the emperor watches over his realm, assigns gods to geographical spaces, and dispatches them to guard their territories from disaster and ward off evil. In other words, Ouyang suggests, in terms of his service to the realm the distinction between life and death is small. ${ }^{48}$ Ouyang makes a well-argued case, and may well have persuaded some local scholars who read this temple inscription. Ouyang's problem, however, is not only the vast majority of worshippers who could

\footnotetext{
${ }^{46}$ Edward L. Davis, Society and the Supernatural in Song China (Honolulu: University of Hawai'i Press, 2001). See also Strickmann, Chinese Magical Medicine.

${ }^{47}$ Strickmann, Chinese Magical Medicine, p. 3.
} 
not read his text, but also the many literati who were not persuaded. 'Only three out of every ten Confucian scholars who live in this area preserve the correct [way of doing things] without deviation. They transform vulgar behaviour without being transformed by this vulgarity. Are we not dependent upon such people? ${ }^{49}$ As Ouyang sees it, fear of harmful ghosts and the abnormal is caused by a lack of understanding, like fear of illness and physical deformities is evidence of a failure to achieve acceptance of one's destiny through learning. ${ }^{50}$ Ever the teacher, Ouyang's answer to what he perceives to be the problem is learning. Understanding heaven ( $z h i$ tian 知天) and learning to the point of accepting one's destiny (xue zhi yu li ming 學 至於立命) are Ouyang's answer to the fear of harmful ghosts and calamities such as illness and plagues. Noble as this counsel might be, more significant is the evidence his inscription provides: most people in mid-thirteenth-century Luling were deeply frightened of Kang Wang.

By the time Liang Qian wrote his inscription for the Baisha temple, around 1400 , that sentiment had not disappeared. This is how Liang describes the powers of Kang Wang:

Since the spirit of the god has become manifest in the South, the presence of his spiritual quality has become even more impressive. His awesome power (yinwei 陰威) and his brutal violence (canlie 慘烈) can truly frighten away demons (shenjian 神奸), while the people who rush to worship him never dare

\footnotetext{
${ }^{48}$ Ouyang, Xunzhai wenji, 16.3a-b.

${ }^{49}$ Ouyang, Xunzhai wenji, 16.4a.

${ }^{50}$ Ouyang, Xunzhai wenji, 16.4b.
} 
to be lax [in their worship]. ${ }^{51} \quad$ Prayers in times of floods and droughts and epidemics always receive a response. The numinous powers of Kang are abundantly clear. $^{52}$

Liang conveys a sense of awe for the power of this god, which originates in the invisible realm, and is based on violence and brutality. Fear is what drives the villagers to worship regularly. Liang, too, attempts to redress this situation with his inscription. 'I worry that people are frightened by the awesome [powers] of the god without knowing about the god's merit. I have therefore expounded on his life, and had [this text] inscribed in stone for the edification of those who worship the god. ${ }^{53}$ Liang, like Ouyang had done before him, sees it as his mission to transform local practice. Liang's text would suggest that in the 150 years that separate the two texts, the overwhelming sense of fear for the god Kang Wang had not disappeared.

While Ouyang identified the spirit medium and the records of the village magician (fang ce) as the source of evil, both for wielding their fear-enhancing powers and for spreading confusion among the shi, Liang Qian blames the Masters of the Way (daojia 道家).

Masters of the Way currently refer to the god as General in the Plague Department (yibu zhi shuai 疫部之帥), [suggesting] he investigates good and evil and administers plagues. This is not necessarily the case. Those who do good receive many blessings; those who do not do good will face many calamities. This is the way of heaven, but it is also always brought about by

\footnotetext{
${ }^{51}$ The term yinwei is used to reflect an awesome quality that stems from the invisible world. Both can and lie have overtones of violence and brutality.

${ }^{52}$ Liang Qian, 'Zhongxiu Baisha Lingyoumiao ji’ 重修白沙靈祐廟記 in Bo'an ji 3.30a.

${ }^{53}$ Liang, Bo'anji, 3.31a.
} 
human affairs. How could Kang be responsible for such things? People whose prayers are artful and deceitful, [spoken with] the intention to avoid punishments and seek blessings are deeply confused. ${ }^{54}$

The evidence suggests that in the eyes of the vast majority, Kang Wang was a powerful, and therefore frightening, spiritual being. Liang expresses his disapproval of those who see Kang Wang as a spirit powerful enough to bestow calamities on people. He suggests that people should ignore the Daoists' representation of Kang Wang as general in the plague department, and recognise Kang as the spirit of the General Kang Baoyi. Ouyang Shoudao’s inscription, Liang Qian's inscription, as well as the encounter between Wen Qiong and Kang Wang in Wen Qiong's hagiography suggest Kang Wang's origins as a dangerous spirit, a hungry ghost, a demon. Scholars like Stephan Feuchtwang and Barend ter Haar have shown that most if not all deities had their origins as hungry ghosts, and Kang Wang clearly was no different. ${ }^{55}$ The abhorrence of the fear and more implicitly of the violence associated with the popularly worshipped Kang Wang that Ouyang Shoudao and Liang Qian display should be seen not as a denial of that demonic origin, but as part of the elite attempt to gloss over those origins. ${ }^{56}$

\footnotetext{
${ }^{54}$ Liang, Bo'anji, 3.30b-31a.

${ }^{55}$ Stephan Feuchtwang, Popular Religion in China: The Imperial Metaphor. (Richmond, Surrey: Curzon, 2001) and Barend ter Haar, 'The Genesis and Spread of Temple Cults in Fukien', in E.B. Vermeer, ed. Development and Decline of Fukien Province in the $17^{\text {th }}$ and $18^{\text {th }}$ Centuries (Leiden: E.J.Brill, 1990), pp. 349-396. Barend ter Haar, The Ritual and Mythology of the Chinese Triads: Creating an Identity (Leiden: E.J.Brill, 1998). Edward L. Davis disagrees, quoting evidence that ancestors could also become gods. See his 'Arms and the Tao: Hero Cult and Empire in Traditional China’ in Sōdai no Shakai to Shūkyō 宋代の社会と宗教 (Tōkyō: Kyūko Shoin, 1985), pp. 1-56 and 'Arms and the Dao, 2: The Xu Brothers in Tea Country' in Livia Kohn and Harold Roth, eds., Daoist Identity: History, Lineage, and Ritual (Honolulu: University of Hawai'I Press: 2002), especially 159161.

${ }^{56}$ Barend ter Haar, 'Rethinking 'Violence' in Chinese Culture' Göran Aijmer and Jos Abbink eds., Meanings of Violence: A Cross Cultural Perspective (Oxford: Berg, 2000), pp. 123-140. Elsewhere Ter Haar discusses what he refers to as the 'demonological paradigm', the presence of the threat of attack by demons as a fundamental aspect of traditional Chinese religious culture. Ter Haar, 'China's
} 
To recognise Kang Wang's origins as a dangerous spirit does of course not mean that Kang Wang was not worshipped for his beneficial powers. For Kang Wang's thirteenth-century believers, the fear Kang Wang inspired was at the same time his greatest asset. By instilling fear, Kang Wang could, for example, fight off bandits, as we see in this inscription by Yang Zhangru.

In the sixth year of the reign of the Son of Heaven, ${ }^{57}$ there were bandits who had armed themselves. They caused unrest in Jiang[nanxi], Hu[guang], Ou [i.e. Zhejiang], and Min [i.e. Fujian]. The people in these areas fled the [bandits] in great panic, ${ }^{58}$ but [the bandits] were so powerful that nothing could stop them. [The bandits] tormented [the area] wantonly. It did not happen merely once that [bandits] looked towards the three counties Jishui, Yongfeng, and Anfu, and felt a desire [for their riches], but they never succeeded in entering the area or approaching the outskirts. The bandits all wondered about this, and some asked for an explanation. One bandit said: 'I wanted to raid these three areas, but when I went, there was a profusion of nuns' banners and flags, [I saw] neat rows of arms and shields, [the area] was full of troops and horses, while fierce winds frightened me. I could not go forward, so I retreated, I ran off. After I calmed down I looked from my hiding place, but the field was empty and the troops were still. Who did this? ${ }^{59}$

The bandits are frightened off by the deity's spirit army, turning out in full force. The answer Yang Zhangru provides for the final question is twofold:

Inner Demons: The Political Impact of the Demonological Paradigm' China Information XI 2/3 (1996):54-88.

${ }^{57}$ Since we know from Yang Zhangru's biography in the Jishui gazetteer that he was close to the Ningzong Emperor, this is probably the sixth year of the reign of Ningzong (r. 1195-1224), i.e. 1200.

${ }^{58}$ Literally, the phrase reads 'encountering wild boars, they scuttled away like snakes'. 
It was the spirit (shen 神) of the Awesomely Manifest, Good and Beneficial, Efficaciously Responsive, Heroically Martyred King. He delivered assistance for the country and for the people. How great is the numinous efficacy of

[Kang] Wang! How abundant his meritorious powers! The spirit of [Kang]

Wang is an Assistant of Dongyue. ${ }^{60}$

Yang provides his readers with two kinds of identity for this spiritual force: Kang Wang as beneficial and officially sanctioned power, ratified by imperial titles, and Kang Wang, the holder of an official post in the divine bureaucracy. While we may speculate why Yang provided this double identification - to impress his readers, to justify his own sanctioning of this spiritual force? - the text does not actually provide evidence that local believers held store by these trappings of official recognition. What matters for those worshipping at this temple is Kang Wang's ability to ward off evil by spreading fear.

\section{The Significance of the Different Representations of Kang Wang}

So far, this discussion has shown that different stories about Kang Wang circulated in thirteenth-century Jiangxi. Despite the different guises in which Kang Wang appears in these stories, one shared characteristic beyond his name and his honorary titles appears in all these stories: Kang Wang inspired fear, suggesting Kang Wang's origins as a demonic spiritual force. As explicit references to Kang Wang's demonic powers disappear by the end of the thirteenth-century, Kang Wang's identity remains undefined. It is clear that the various identities for Kang Wang that coexist were

${ }^{59}$ Jishui xianzhi (1875) 12.22b-23a.

${ }^{60}$ Jishui xianzhi (1875) 12.23a. 
created for different reasons in different contexts. To understand the variety in Kang Wang's representations and the ambiguity in his identity, we need to look more closely at the ways in which the different authors provide identities for the otherwise unidentified, ambiguous spiritual force. We need to ask who does the identifying, in what context, and for what reason. I suggest that naming the deity, providing an identity and a personal history, should be understood as attempts to exert control over an otherwise uncontrolled demonic force. ${ }^{61}$ To explore this apotropaic use of a deity's identity in more detail, we need to revisit the extant writings about Kang Wang with special attention to the process of identification within the text.

\section{Identifying the Demon as Kang Baoyi}

We have already established that Ouyang Shoudao objects to the frenzied worship carried out at Kang Wang shrines in Luling, and advocates worship that celebrates the moral values represented by Kang Baoyi's life. ${ }^{62}$ But on what basis does Ouyang Shoudao historicise Kang Wang? Why the association with Kang Baoyi? Although Ouyang's inscription is the oldest extant reference to a link between Kang Wang and Kang Baoyi, that link is unlikely to be entirely the fruit of Ouyang's imagination.

[Kang] Wang was from Luoyang, and he died in Hejian. There are no traces of him south of the Great River, but since the fall of the Northern Song, awesome spiritual powers have been manifest in this area. How could anything be more loyal than his life and his sacrificial death for the dynasty? After Central China had undergone the trauma of the Jingkang reign [in 1126],

\footnotetext{
${ }^{61}$ Seidel, 'Imperial Treasures and Taoist Sacraments', p. 320-332.

${ }^{62}$ This is a clear example of the kind of elite condemnation of violence that Barend ter Haar discusses in his work. See, among others, his 'Rethinking 'violence' in Chinese Culture'.
} 
people schemed to recover his body, which had not been buried, and soon

[thereafter] the heroic spirit of the martyr was positively identified on the basis of the existence of his clothing and his official headdress. ${ }^{63}$

A historical figure, a general, dies a cruel death at the hands of foreign invaders on the battlefield in the far north. More than one hundred years later a spirit manifests itself in Luling. A link is then established, although the historical figure never set foot south of the river, on the basis of what are thought to be relics of the martyr, who gave his life for the dynasty. Ouyang's account does not clarify whether a shrine was established on the battlefield, and his cult carried south after 1126, or whether the first shrine appeared in the south. Perhaps the unidentified relics of a person who met a violent death only later came to be associated with the general who had died in heroic but equally violent circumstances. While the specifics of this case remain speculative, scholars like Barend ter Haar, Stephan Feuchtwang and others have shown that numinous powers were commonly ascribed to those who died violent deaths. ${ }^{64}$

Although Ouyang claims to disapprove of popular worship in Luling, the process he describes here could come directly from the mouth of an informant describing popular religious practice today. Shrines for the unidentified dead often become a focus for both fear and gratitude. Feuchtwang writes,

\footnotetext{
${ }^{63}$ Ouyang, Xunzhai wenji, 16.2a.

${ }^{64}$ A great deal of work has been done to show this to be the case, most notably by Barend ter Haar. See, for example, Ter Haar, Ritual and Mythology of the Chinese Triads; 'Genesis and Spread of Temple Cults'; 'Local Society and the Organization of Cults in Early Modern China: A Preliminary Study' Studies in Central and East Asian Religions 8 (1995):1-43. As Barend ter Haar points out, anthropologists have long noted the numinous powers associated with violent death. See also UrsulaAngelike Cedzich, 'The Cult of the Wu-t'ung/Wu-hsien in History and Fiction' in David Johnson, ed., Ritual and Scripture in Chinese Popular Religion (Berkeley: Publications of the Chinese Popular Culture Project 3, 1995), pp. 137-218. Rolf Stein's work demonstrates that people who died violent deaths frequently became the subject of cults in pre-Tang society. Rolf A. Stein, 'Religious Taoism and Popular Religion from the Second to Seventh Centuries' in Holmes Welch and Anna Seidel, eds., Facets of Taoism (New Haven and London: Yale University Press, 1979), pp. 53-82. See also the
} 
They are intermediate, with some people despising and fearing and some people feeling helped by having placed offerings at them. ... Once they are treated as gods - or was it a precondition for their being so treated? - they gain an identity and a biography. The names and lives of those known to have died at the site are told as legends. Frequently that is as a fighter or gang of fighters, for these shrines are typically for those who died a violent death. ${ }^{65}$

Is this not very similar to the process described by Ouyang? Perhaps we can reconstruct the following events. At a shrine for the unidentified dead, some place offering to placate the hungry ghosts, others make offerings in gratitude for received assistance. The spirit then receives an identity; in this case stories are told of the violent death of General Kang Baoyi at the hands of enemy soldiers. His soul is uncared for, his body irretrievable first in distant lands invaded by Khitan, then in enemy territory occupied by the Jin, but his identification is 'proven' on the basis of articles of clothing recovered after the fall of the north. ${ }^{66}$

The identifying legends are clearly important. As Ouyang writes, 'Every day there are new fabrications and lies are further embellished, especially those relating to his control over epidemics. ${ }^{67}$ Feuchtwang's parenthetical question is, I would argue, crucial. 'Once they are treated as gods — or was it a precondition for their being so treated? - they gain an identity and a biography.' It seems to me that establishing an identity and providing a biography can be understood not just as a way of representing

discussion in Glen Dudbridge, 'Yü-ch'ih Chiung at An-yang: An Eighth-Century Cult and Its Myths.' Asia Major, Third Series, Vol. III, Part I (1990):27-49.

${ }^{65}$ Feuchtwang, Popular Religion, 48. See also Stevan Harrell, 'When a Ghost Becomes a God' in A. Wolf, ed. Religion and Ritual in Chinese Society (Stanford: Stanford University Press, 1974).

${ }^{66}$ Edward Davis disagrees with the idea that this anthropological model could also apply to cults in traditional China. See his discussion of this issue in 'Arms and the Tao', especially pages 26-30.

${ }^{67}$ Ouyang, Xunzhai wenji, 16.2b. 
a demonic force as a worthy god, but as a way for Ouyang Shoudao of bringing about that transition from demon to deity. Ouyang Shoudao's 1248 text reflects the various stages in the process, which may have looked like this. The god's origins as a hungry ghost, one of the many unidentified dead, would explain the worship fuelled by fear Ouyang describes. Once some associate a blessing that has befallen them with worship at this shrine, stories that identify the ghost as Kang Baoyi begin to appear. The next stage in the development is seeking official recognition for the god, which Kang Baoyi receives, although Ouyang makes it sound as if the request was instigated by the imperial court. 'When the emperor initiated the reorganisation of the gods of the prefectures and counties, requests were submitted for the enfeoffment of and the presentation of titles to [Kang] Wang, and both were granted immediately. ${ }^{68}$ The local magistrate then deems the shrine worthy of his worship:

A certain Mr Li of Yuzhang 豫章李侯某 received the imperial command to be magistrate in the area. He prayed to the god about the affairs of the people. As soon as he had uttered his words, the response followed [as fast as] an echo, and this answer proved to be true. ${ }^{69}$

The final stage, so far as we can trace it here, is the request for the local scholar and notable, Ouyang Shoudao, to grace the shrine with an inscription. Rather than merely praise the blessings brought by the deity and celebrate the structural improvements funded by the magistrate, the usual content of such temple inscriptions, Ouyang offers a thorough critique of the worship at this shrine. He denounces the stories about Kang Wang as fabrications and lies, claims that it is these stories that frighten the ordinary

\footnotetext{
${ }^{68}$ Ouyang, Xunzhai wenji, 16.2a.

${ }^{69}$ Ouyang, Xunzhai wenji, 16.3b-4a.
} 
worshippers ('Ignorant common people are frightened by such falsehoods about demons (yao e 妖讹), which no one can put a stop to ${ }^{70}$ ) rather than the god's hungry ghost origins, and suggests that people focus instead on the loyalty and bravery exemplified by the heroic Kang Baoyi.

Ouyang Shoudao's temple inscription, while detailed, does not provide enough evidence to prove each of these stages, and this discussion may provide only one of several plausible readings. Beyond doubt is, however, that Ouyang dislikes the worship he observes at this shrine, and that he advocates worship of a figure with Confucian credentials, who died in the service of the emperor. Ouyang Shoudao uses his temple inscription to emphasise the historical Kang Baoyi over the powerful spirit worshipped at this shrine. By providing details based on Kang Baoyi’s Songshi biography and by stressing the details of Kang's lifetime rather than the details of his violent death or his uncared for spirit, Ouyang attempts to forge a transition: his writing is an attempt to turn the subject of popular worship into a deity worthy of morally edifying worship. I would argue that Ouyang Shoudao's 1248 inscription provides a fascinating picture of a brief stage in the much more gradual process of transformation from demon to deity. At the time of Ouyang's writing, that transition was not yet complete, and the tension between Kang Wang's popular demon worship and Ouyang's preferred interpretation is still palpable.

One might ask why Ouyang Shoudao, who so clearly disapproved of the worship at Lingyou Temple, took the trouble to write this long inscription. Why not simply ignore the temple, or denounce it as a wanton shrine (yinci)? That Ouyang used this opportunity to expound his views on worship and local ritual suggests that he

\footnotetext{
${ }^{70}$ Ouyang, Xunzhai wenji, 16.3a.
} 
considered the temple inscription a worthwhile format for expressing his views. His audience, most likely members of the local elite like himself, would have recognised Ouyang's interest in local religious practices. As I have suggested elsewhere, the Southern Song and Yuan local elites in Luling wrote about local temples and rituals as a way of emphasizing their own importance within the local cultural realm. ${ }^{71}$ By writing about a locally powerful temple, Ouyang could show that he 'belonged' locally, and at the same time create the impression among his fellow elite gentlemen that his voice carried authority within the local community. We will never know for sure to what extent Ouyang succeeded in enhancing his own standing in local society by writing this inscription, but we do know that his text would be quoted in texts about Kang Wang for many centuries to come. ${ }^{72}$ For Ouyang Shoudao, this temple inscription was a way of imposing his own representation of the cult, even if local worshippers continued to ignore Kang Baoyi’s fondness for Confucian rituals.

\section{Identifying the Demon as Dongyue's Assistant}

Let us assume for a moment that the analysis of Ouyang's inscription offers a possible explanation for the literati association of Kang Wang with Kang Baoyi, an association overwhelmingly followed by scholars into the twenty-first century. ${ }^{73}$ We need to ask,

\footnotetext{
${ }^{71}$ Anne Gerritsen, 'Gods and Governors: Interpreting the Religious Realm in Ji' an (Jiangxi) during the Southern Song, Yuan and Ming Dynasties'. PhD, Harvard University (2001). Especially chapter six. See also Gerritsen, 'Liu Chenweng (1232-1297): Ways of Being a Local Gentleman in Southern Song and Yuan China' In The Human Tradition in Premodern China, Kenneth J. Hammond, ed. (Wilmington: Scholarly Resources, 2002), pp. 111-125.

${ }^{72}$ Exerpts of Ouyang's inscription appear, for example, in Luling xianzhi (1825) 9.12b-13a; Yu Zhengxie, Guisi cungao, 13.409.

${ }^{73}$ Of a total of 51 different references to Kang Wang I have found, less than ten do not identify Kang Wang as Kang Baoyi. Some of these were written before Ouyang's inscription, and some were written in the late Qing, when several scholars became interested in the question of Kang Wang's identity. Many refer to Ouyang's inscription as the locus classicus for Kang Wang's identification as Kang Baoyi.
} 
then, how this fits with the Daoist identification of Kang Wang as one of Dongyue's assistants. The professional Daoists see Kang Wang as general in the celestial bureaucracy concerned with plagues, where he operates as a subordinate in the retinue of Dongyue. ${ }^{74}$ The hagiography of Marshal Wen suggests that this representation should similarly be read as an attempt at imposing an identity considered more suitable onto a less desirable identity. As we saw above, the Kang Wang Marshal Wen encounters is far from an obedient servant in the bureaucratic ranks. He competes with a local Perfected Being for supremacy, wielding his plague-spreading powers to impress the locals, and displaying his charms and seals to underline his bureaucratic status. His crimes are efficiently dealt with by Marshal Wen, with which Daoist authority over this rogue spirit is reasserted. The hagiography can, as Katz suggests, be read as propaganda for the Daoist cause. ${ }^{75}$ As Marshal Wen subjugates Kang Wang, one more local (ecstatic) cult has been replaced with the pure rituals of Daoism. Kang Wang the frightening spirit is thereby replaced by Kang Wang, one of the ten generals in the retinue of Dongyue. The literati and the professional Daoists are engaging in a very similar process. Both integrate the demonic force into their own system of rituals and values.

This raises the question of which came first. Is it possible to determine when Kang Wang was first promoted to assistant of Dongyue? The oldest reference I have found to a Kang Wang in the retinue of Dongyue occurs in Yang Zhangru's inscription:

\footnotetext{
Interestingly, of the many Kang Wang temples I visited around Ji'an in September 2002, only the rebuilt Lingyou Temple at Baisha referred to Kang Baoyi.

${ }^{74}$ Kang Wang is mentioned by Lü Zongli as one of the ten Grand Guards (taibao) of Dongyue, together with Wen Yuanshuai (Wen Qiong) and Zhang Xun. Lü, Zhongguo minjian zhushen, p. 349.

${ }^{75}$ Katz, Demon Hordes, p. 86.
} 
'The spirit of [Kang] Wang is an Assistant of Dongyue. ${ }^{76}$ Most likely, this text was written during the 1220 s or 1230 s, which would make the Daoist version of Kang Wang older than Ouyang Shoudao's Confucian version, but it is difficult to ascertain any further details, since Yang Zhangru's complete works (Dongshan wenji 東山文集) have been lost. Without access to Yang Zhangru's full text, ${ }^{77}$ it is hard to tell whether he assumed Kang Wang's status in the Daoist hierarchy to be common knowledge or in need of further justification and explication. Wu Zimu's 吳自牧 Mengliang $l u$ 夢梁 錄, compiled in the late thirteenth or early fourteenth century, ${ }^{78}$ states:

The Guangling 廣靈 Temple is at Shitang 石塘. It is dedicated to General Wen of Dongyue. Below Wen there are nine gods. They have all been enfeoffed as lords. ... Kang has been given the title Anyou 安佑. ${ }^{79}$

It suggests that by the late thirteenth century, that association had become widespread.

Where does that leave the 1274 hagiography of Marshal Wen? We know that Huang Gongjin represented Kang Wang as a dangerous spirit, who spread disease and had to be subdued by Marshal Wen, and that the hagiography can be read as a snapshot of a moment in a much longer transitional process, in which pure Daoism was established over the bloody sacrifice of local cults. But when was the snapshot taken? The date of the hagiography, 1274, would seem somewhat late compared to Ouyang's 1248 text. Could it be that Huang Gongjin's text incorporates narratives that have

\footnotetext{
${ }^{76}$ Jishui xianzhi (1875) 12.23a.

${ }^{77}$ Frequently, inscriptions ( $j i$ 記) included in gazetteers were not complete. For example, Ouyang's text, frequently included in gazetters from all the counties of Ji'an prefecture, is usually abbreviated to about two pages, while the full version in his literary collection covers more than eight pages.

${ }^{78}$ The source is diffcult to date, but 1304 has been suggested as a possible date for the preface. Wilt Idema and Stephen West, Chinese Theater 1100-1450: A Source Book (Wiesbaden: Franz Steiner, 1982), p. 14.
} 
circulated for some time? To prove that would take a good deal more exhaustive research, but Kang Wang's title, mentioned when Kang Wang is first introduced to the reader, is interesting. It is given as Awesomely Helpful, Good and Beneficial, of Broad Kindness, the Heroically Martyred King (weiji shanli fuhui yinglie wang). Seven of the eight characters of the honorary title listed here are identical to the characters listed in Yang Zhangru's inscription. According to Yang, Kang Wang had received these characters (weiji shanli fuying yinglie 威濟善利孚應英烈) by the Qingyuan reign period, between 1195 and 1200. As Yang writes, 'During Baoqing [1226-1227] they increased his honours by replacing the character $j i$ (assistance) with xian (manifest), and replacing $f u$ (foruitous) with ling (numinous). The title was beautified, but no characters were added. ${ }^{80}$ The Baoqing title, 威顯善利靈應英烈, is the honorary title listed in Ouyang Shoudao's inscription. Could it be that the 1274 hagiography incorporates an older story, one that came into being between 1200 and 1226 , i.e. in the brief period of time that Kang Wang was known with the older title (weiji shanli fuying yinglie wang)? Unfortunately, this has to remain entirely based on speculation, but perhaps it is not impossible to imagine that the Huang Gongjin text reflects tensions and conflicts between Daoism and a variety of local cults that took place over an extended period during the twelfth and thirteenth centuries.

\section{Other Kang Wangs}

These two examples, the Confucian Kang Wang and the Daoist Kang Wang, both provide evidence for the idea that different identities for Kang Wang coexist because

\footnotetext{
${ }^{79}$ Wu Zimu, Mengliang lu (1274, reprinted in Dongjing Menghua lu 东京梦华录 (wai si zhong 外四 种) Beijing: Wenhua, 1998), 14.245.
} 
they came into being in different socio-religious contexts, to serve the needs of different individuals. Both offer an alternative to the demonic identity of Kang Wang. What about the other identities for Kang Wang? Can we observe similar processes there? The late Ming Sanjiao yuanliu soushen daquan 三教源流搜神大全 introduces an entirely different Kang. ${ }^{81}$ While there is no separate entry for Kang Wang, there is a biography for Marshal Kang (Kang yuanshuai 元帥). Marshal Kang is the son of Kang Qu 康獸 and Lady Jin 金氏, known for his gentle behaviour during his lifetime.

He rarely got angry, and even when [a place] was teeming with crawling insects, he did not take killing insects and worms lightly. He fed on fallen flowers, and only drank pure juices. Once a stork chick was caught by a falcon, who dropped [the chick] after having broken its wings. He retrieved [the chick] from where he was lying, and fed the bird by chewing food for it. ${ }^{82}$ Once the reputation of this man's healing powers spread from the villages to heaven, the emperor of heaven enfeoffed him with the title Benevolent Sage Marshal (rensheng yuanshuai 仁聖元帥). The illustrated version of Sanjiao yuanliu soushen daquan includes a drawing of a Marshal Kang looking somewhat fiercer than his hagiography suggests, holding a golden axe ( $f u$ 斧) in his left hand, and in his right hand what the

${ }^{80}$ Jishui xianzhi (1875) 12.23a-b.

${ }^{81}$ Sanjiao yuanliu soushen daquan 三教源流搜神大全 was reprinted in 1909 by the book collector and publisher Ye Dehui 葉德輝 (1876-1927). For further details on the history of this text, see Katz, Demon Hordes, 93n40. There is an earlier, Yuan, edition for this text, entitled Xinbian lianxiang soushen guangji 新编连相搜神广记, but this edition does not include Kang Wang or Kang Yuanshuai. Both editions are included in the Shanghai guji edition. Huitu sanjiao yuanliu soushen daquan (wai er zhong), (Shanghai, Shanghai guji chubanshe, 1990).

${ }^{82}$ Sanjiao yuanliu soushen daquan (1909, reprint ed. Shanghai, 1990), p. 240. 
text refers to as 'a melon hammer (guachui 瓜鎚) and a jade seal (xi 䨝) that rotate'. ${ }^{83}$ Of course this Marshal Kang may be entirely unrelated to our Kang Wang. The contemporary scholar Lü Zongli 呂宗力 acknowledges the unresolved confusion over Kang Wang's identity, diplomatically leaving all interpretative options open. He justifies his decision to separate Kang Wang from Marshal Kang into two lemmas in his book by suggesting that it is quite possible that Kang Wang is one of the nine dukes of Dongyue, referring his readers there for more details. ${ }^{84}$ It would seem at the very least conceivable that the demon (or deity, or 'demon/deity' to indicate its transitional status) represented by Luling literati as the general Kang Baoyi is the same as the demon/deity given this hagiography in the Sanjiao yuanliu soushen daquan.

The question we need to ask, then, is why the demon/deity is given this particular identity. Why so little emphasis on specific skills or superior qualities, why so few details about where he was born or where he lived? Why, more to the point, the emphatic denial of violence? 'During his lifetime, the Marshal was benevolent and kind. He did not injure foetuses, take the life of the young, or violate children and orphans. ${ }^{85}$ Is it possible that this image of a man chewing and regurgitating food to save the life of a stork chick is created for the purpose of denying or undermining more violent tales told about him? Could representing the god as someone who would not kill a fly be read as an act to exorcise the evil spirit? The parallel this provides with Ouyang Shoudao's gentrification of the god makes the thought worth considering, even if it remains speculative.

\footnotetext{
${ }^{83}$ Ibid. The picture is on p. 239.

${ }^{84}$ Lü, Zhongguo minjian zhushen, p. 702-3.

${ }^{85}$ Sanjiao yuanliu soushen daquan, p. 240.
} 
One Kang Wang has so far remained undiscussed: Zhou Kang Wang. Of course shrines for King Kang of the Zhou dynasty could be an entirely different kettle of fish from the shrines of popular worship discussed thus far. It would seem, however, that the same process of using a 'suitable' identity to cover up an 'unacceptable' identity is at work here. King Kang, son of King Cheng, ruled during the Western Zhou, between 1004 and 967 BCE. He would later be known for his pacification of the southeast, and for the peace and tranquility of his reign. It was said, 'During the reigns of Cheng and Kang there was peace in the realm, and for over forty years it was not necessary to implement punishments. ${ }^{86}$ According to one Qing author, Huang Zhongjian 黃中堅 (dates unknown), who wrote an inscription for the Kang Wang temple in Suzhou, Kang Wang's association with peace and an absence of corporeal punishments made him the ideal god for worship near execution grounds. ${ }^{87}$ 'Tieping Alley used to be the place where they punished people. There were many ghosts, thus they built a temple for the king of the Zhou to ward them off, because during the time of King Kang of the Zhou punishments were not implemented. ${ }^{, 88}$ A site used for executions and therefore haunted by the restless souls of the uncared for dead, becomes known in literati writings as the site for worship of the King of the Zhou dynasty, famous for his peaceful reign.

Yu Yue, the author of Chaxiangshi xuchao, who had read Huang Zhongjian's inscription, disagreed with Huang Zhongjian, suggesting that the Kang Wang temple in Suzhou was not necessarily a temple for King Kang of the Zhou:

\footnotetext{
${ }^{86} \mathrm{Wu}$ Hailin 吴海林, ed., Zhongguo lishi renwu cidian 中国历史人物辞典 (Harbin: Heilingjiang renmin, 1983), p. 4.

${ }^{87}$ The only help available for dating this source is its inclusion in an 1847 source.

${ }^{88}$ Quoted in Zhuding yuwen, pp. 157-158.
} 
Huang Zhensheng 黃震生 [i.e. Huang Zhongjian] from Wu County has an inscription in Zhongjian Xuzhai ji 中堅蓄齊集. He thinks [this temple] is for King Kang of the Zhou. ... Later I read [Yu Zhengxie's] Guisi cungao, ${ }^{89}$ and then knew that there are many extant Kang Wang temples, but that this Kang Wang temple is not necessarily a temple for King Kang of the Zhou. ... I thought they built Kang Wang temples to ward off ghosts, which is precisely the point of worshiping Kang and Zhang $[\mathrm{Xun}]^{90}$ together. For generations people have worshipped Zhang Xun because he chases off harmful ghosts. If so, then it makes sense that they build Kang Wang temples where there are many ghosts. ${ }^{91}$

From Yu Yue's description, it would seem that Kang Wang temples are often built in places infested with harmful ghosts in order to ward off the ghosts. But those who are worshipped for their protection against demons often started their careers themselves as demons. ${ }^{92}$ The 'logic' of worshiping King Kang of the Zhou on a demon-infested site because during his reign corporeal punishments were not needed sounds too much like a literati invention to be universally followed, and even $\mathrm{Yu}$ Yue seems unpersuaded. Huang Zhongjian's inscription is no longer extant, so once again we cannot say for sure how widely accepted the association was between the Kang Wang temple of Tieping Alley in Suzhou, and King Kang of the Zhou, but surely, here too, the identification may serve an active purpose. It would seem very likely that the Kang Wang of

\footnotetext{
${ }^{89} \mathrm{Yu}$ Yue refers here to Yu Zhengxie, 'The God Kang Wang', Guisi cungao, 13.408-409.

${ }^{90}$ Zhang Xun 張巡 (709-757) was a famous Tang dynasty general, whose worship was widespread throughout Jiangxi, and who was often worshipped together with Kang in Qing dynasty Jiangxi.

${ }^{91}$ Chaxiangshi xuchao, juan 19, quoted in Lü, Zhongguo minjian zhushen, p. 701-2.

${ }^{92}$ Strickmann compares this process to homeopathic medicine. 'Figures originally (and no doubt, marginally, still) functioning as disease-demons have by the early medieval period become homoepathic
} 
Tieping Alley is identified as King Kang of the Zhou (his 'suitable' identity) so that worship of a demon that keeps other demons at bay (Kang Wang in his unacceptable guise) is represented as the morally exemplary worship of one of the Zhou kings. Certainly when a Wang Yinglin 王應遴 writes about a Kang Wang temple in Gao'an 高安 county in Ruizhou 瑞州 prefecture to commemorate its 1622 restoration, he finds it hard to explain the link between the god who had healed the magistrate's son from a serious illness in 1614, and the Zhou king. 'There are no details about why the people of Jun 筠 built this shrine, and there is no record of when the King first brought blessings to this area. ${ }^{93}$ What matters to Wang Yinglin is that the god continues to protect the area, and that the record of his merits is preserved for prosperity.

In this discussion of the various identities of Kang Wang it has become clear that on the level of the worshippers, his identity is in many ways unimportant. There is no indication in Wang Yinglin's text that the population in the city of Jun worshipped the god for any other reason than the blessings he brought. There is little doubt in my mind that neither the believers in thirteenth-century Luling who feared the tales about Kang Wang's demonic powers, nor the believers in 1996 Ganzhou who could only offer very vague and incoherent answers to Zhang Sijie's questions about Kang Wang's identity, nor the villagers around Ji'an in 2002 cared much about Kang Wang's full name or his hagiographic details. In their experience Kang Wang had powers that were feared as much as praised. So long as he continued to protect the area, he was the local benefactor.

protectors against the very ailments which previsouly, in their old, unenlightened, pre-Buddhist days, they had themselves provoked.' Strickmann, Chinese Magical Medicine, p. 67. 
For a local benefactor, however, Kang Wang seems to have a very loose connection with the area. The relationship between Kang Wang and the Luling area is completely different from the relationship between, for example, the Huagai 華蓋 Immortals and their mountain. Hymes makes clear that one of the characteristics of his personal model is a god's link to place, which he describes as 'inherent or founded in the god's own choice, and as permanent (italics not mine),' and the Huagai Immortals are perfect examples of such a strong local connection. ${ }^{94}$ The Huagai cult was known for the close link to its mountain, as it gained fame throughout the realm among literati by being listed in Wang Xiangzhi’s 王象之 Yudi jisheng 與地紀勝, the 1227 tourist guide-book for the Southern Song realm. Despite Yang Zhangru's mid-thirteenth-century claim that worship for Kang Wang had spread throughout Southern Song China, it seems unlikely that the cult of Kang Wang was a well-known regional cult. The cult is not listed at all in the Yudi jisheng description of Jizhou, as it is not linked to a specific geographical feature or location. ${ }^{95}$ Zhu Mu's 祝穆 (?after 1246) Fangyu shenglan 方耝勝覽, a Southern Song dynasty topography of scenic locations, mentions only three temples in Jizhou: Daming 大明寺 and Nanta Temples 南塔寺 in Taihe, and Chongyuan Daoist Monastery 崇元觀 in Jishui, which the immortal Lü Dongbin 吕洞宾 was said to have paid a visit, but again, no reference is made to Kang Wang. ${ }^{96}$ There is a possible link between King Kang of the Zhou and Jiangxi: according to the Bamboo Annals (Zhushu jinian 竹書紀年), in the sixteenth

\footnotetext{
${ }^{93}$ Wang Yinglin, 'Inscription for the Kang Wang Temple' Gao'an xianzhi 高安縣志 (1871) 23.23a. ${ }^{94}$ Hymes, Way and Byway, p. 5.

95 The section on Jizhou is juan 31. Wang Xiangzhi, Yudi jisheng [1227] 1962, 364-375. The eleventh-century Yuanfeng jiuyu zhi 元豐九域志 also does not mention any sites of worship for Kang Wang.
} 
year of the reign of Kang Wang (989 BCE), the king went south on an imperial tour to the Lu Mountains 庐山 in Jiujiang 九江, and hence a several locations in the $\mathrm{Lu}$ Mountains are named after King Kang of the Zhou. ${ }^{97}$ The origin of the link between Kang Baoyi and Luling, however, and of the link between Marshal Kang and Luling remain hard to establish. If Kang Wang was worshipped as a local benefactor in thirteenth-century Jizhou and beyond, the model for that worship was clearly different from the personal model as Hymes describes it.

\section{Conclusion}

Kang Wang could thus be worshipped as a local benefactor without having a clearly established connection to the local area. Significantly, neither the identity of the god, nor the exact nature of his link to the area mattered much to the ordinary believers of Kang Wang. It did, however, matter a great deal to those whose attentions to this cult were driven by a particular agenda. I would argue that for them establishing who this unidentified demon/deity was, and proclaiming that identity with the greatest authority was an extremely important act. For a literatus like Ouyang Shoudao, emphasising that Kang Wang should be worshipped as Kang Baoyi was a way of drawing attention

\footnotetext{
${ }^{96} \mathrm{Zhu} \mathrm{Mu}\left(13^{\text {th }}\right.$ century), Fangyu shenglan (n.d., reprint ed. Shanghai, 1986) 20.10a.

${ }^{97}$ Zhuding yuwen quotes this section from Zhushu jinian on page 157. Chen Shunyu's 陈舜俞 (?1074) eleventh-century Lushanji 庐山记, for example, frequently refers to scenic sites named after Kang Wang. See, for example, the beginning of juan 3: 'Twenty $l i$ from Yuantong is Jingde Monastery 景德观 of Kang Wang Valley 康王谷. It's old name was Kang Wang Monastery 康王观. When you enter the valley, and go upstream for five $l i$, you come to Longquan Hall 龙泉院. After another twenty $l i$ there is a waterfall. The water spurts out of the spring, hits the rocks, and cascades down in twenty to thirty different streams. It's height cannot be measured, but it is over $70 \mathrm{chi}$ wide.' Chen Shunyu, Lushan ji (SKQS edition) 3.1a. Here, too, there is doubt over the true identity of Kang Wang: 'Tradition has it that King Kang of Chu 楚 was a general of Qin 秦. The King cut [the heads] of those who were causing difficulties, and hid in this valley. Later he became a hermit here, and hence the name Kang Wang Valley. The stele inscriptions of the monastery all confirm this, but having researched it, I find this not so. Kang Wang of Chu died in the $28^{\text {th }}$ year of the reign of Lord Xiang of
} 
away from the demon Kang Wang and his frenzied spirit-medium-led worship. For Huang Gongjin, showing Kang Wang as plague-spreading demon and submitting him to the authority of Marshal Wen and Dongyue was a way of showing the successful subjugation of local cults to Daoist supremacy. Literati like Ouyang Shoudao and Yang Zhangru, and Daoists like Huang Gongjin wrote about Kang Wang in part to provide evidence for the success of their 'civilising project'. In the representation of the god they present to their audience, the demon has successfully been 'civilised', although opinions differ whether they were successful, and whether the civilising agent was the Confucian state represented by the literati or Daoist officialdom. For Huang Zhongjian, the god worshipped at the site of executions was represented as King Kang of the Zhou, his tranquil reign contrasting sharply with the violence of the punishments. For the majority of the worshippers at Kang Wang shrines, Kang Wang represented a spiritual power. That spiritual power might be ambiguous, and worship over time seems to have remained a mixture of gratitude for his blessings and fear for the harm he might do, but those spiritual powers remain in the case of Kang Wang the most important, or perhaps the only important aspect of his identity. It is only those who interpret Kang Wang worship on a more intellectual level—authors of inscriptions, hagiographies, local officials and government representatives — who are dissatisfied with this ambiguous demon/deity. In their writings they attempt to placate the demon and turn him into a god by identifying him. They choose identities of their own liking of course, ones that suit both their own outlook and the site of the worship, hence the great variety in identities for Kang Wang, but their written identifications all share one

Zhou [r.651-619 BCE, i.e. 624 BCE]. He was buried outside the western gate by the gentlemen of Lu, Chen, Zheng and Xu.' Chen, Lushan ji, 3.1a-b. 
thing: they attempt to turn Kang Wang from a potentially harmful demonic power to a beneficent, worthy god. 